\title{
Finn Wiedemann: Uddannelse under naturlig forandring
}

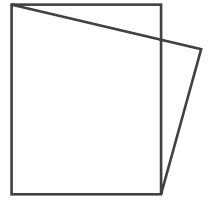

Anmeldt af Steen Juul Hansen, docent, Center for Virkningsfuld Praksis, VIA University College
Bogen er på 123 sider og er disponeret på syv kapitler foruden en indledning. Der er tale om en 2. udgave. Den første udgave kom i 2011. Målet med bogen er at give et teoretisk-analytisk bud på sammenhængen mellem ændringer inden for den danske uddannelsesverden og den samfundsmæssige og kulturelle udvikling. Et andet sigte med bogen er at komme et skridt videre end blot at pege på, at træk ved den samfundsmæssige og kulturelle udvikling er skyld i dette og hint. Målgruppen er studerende, der beskæftiger sig med læring, dannelse og pædagogik, men også forskere og undervisere med interesse for pædagogiske emner og uddannelsesområdets udvikling.

Det første kapitel behandler betydningen af bogens titel "Uddannelse under naturlig forandring". Det fremgår, at generelle politiske, økonomiske og sociale ændringer i samfundet har større indvirkning på uddannelsesområdet end de planer og projekter, som sektoren selv sætter i gang. Så i den forstand kan man tale om, at uddannelsesområdet er i en naturlig forandringsproces. En forandringsproces drevet af generelle forandringer i samfundet. En vigtig pointe i dette kapitel er, at udviklingen i samfundet skal ses som strukturationsprocesser, hvor menneskets handlinger på samme tid strukturerer og er struktureret af samfundet.

Det er bogens hypotese, at de naturlige samfundsændringer indirekte bidrager til at omforme det danske uddannelsessystem, og at ændringerne har en selvstændig forklaringskraft i forhold til at tematisere de ændringer, der har fundet sted. Bogen arbejder med følgende fire overordnede tendenser: 1) Globalisering, 2) Overgangen til videnssamfundet, 3) Konkurrencestaten og 4) Senmoderniteten, herunder de ændrede vilkår for individets identitetsdannelse. De nævnte udviklingstendenser sætter uddannelsesverdenen under et krydspres, som det enkelte uddannelsesom- 
råde og den enkelte uddannelsesinstitution skal navigere i. Empirien for bogens analyser er ny uddannelseslovgivning, ministerielle publikationer, debatlitteratur og videnskabelig litteratur.

Efter indledningskapitlet følger fire kapitler, der hver især behandler, hvordan henholdsvis globaliseringen, videnssamfundet, konkurrencestaten og sen-moderniteten påvirker uddannelsesområdet. De fire kapitler udgør bogens analyser. Alle fire kapitler er bygget op på nogenlunde samme måde med først en redegørelse og diskussion af relevant teori efterfulgt af et afsnit om konsekvenserne for uddannelse. Kapitlet om globalisering trækker primært på teorier af A. Giddens og P. Jarvis. Kapitlet om vidensamfundet trækker på flere forskellige teoretikere, heriblandt P. Jarvis. Kapitlet om konkurrencestaten trækker på danske bidrag om, hvordan vilkårene for ledelse og organisering har ændret sig de seneste år. Det er eksempelvis Åkerstrøm-
Andersen, O.K. Petersen samt Ejersbo og Greve. Endelig trækker kapitlet om sen-moderniteten på teorier af eksempelvis Z. Baumann og A. Giddens.

Bogen afsluttes med et sammenfattende kapitel og et meget kort afslutningskapitel. Det fremgår af afslutningskapitlet, at udviklingen inden for uddannelsesområdet er præget af modsætningsfyldte tendenser, og at kampen om fremtiden derfor er et uafsluttet kapitel. Det er ikke entydigt, hvad vej udviklingen går. Det fremgår af sammenfatningen, at styrkeforholdet mellem staten, markedet og civilsamfund og kulturen har forrykket sig til fordel for markedet og staten, hvor staten agerer som drivkraft eller velvillig arkitekt i denne udvikling. Når uddannelsesområdet sættes til debat, sker det i en økonomiske forklaringsramme fremfor i en kulturel og kultursociologisk. ÆEndringerne inden for uddannelsespolitikken afspejler, at bestemte samfundsmæssige interesser og gruppers indflydelse spiller en mere dominerende rolle inden for uddannelsesfeltet, end det rent historisk har været tilfældet tidligere. Der er imidlertid mulighed for at påvirke og balancere den uddannelsespolitiske udvikling. Som forfatteren formulerer det, så er vi ikke kun ofre for den samfundsmæssige og kulturelle udvikling, men vi har både et medansvar for og handlemuligheder $\mathrm{i}$ forhold til, hvordan naturlige ændringer sker. Historien fremstår som et uafsluttet projekt uden endemål. Så den naturlige forandring af uddannelsen er ikke mere naturlig, end vi gør den til.

Sammenfattende kan man sige, at bogens hypotese om, at de naturlige samfundsændringer bidrager til at omforme det danske uddannelsessystem, bekræftes.

Bogen er en 2. udgave, hvor teorier, tendenser, analyser og eksempler er ført op til i dag. Når man læser bogen fremgår det ikke klart, hvad der er forskellen 
Tema: Professionshøjskoler i 10 år

mellem 1. og 2. udgaven. Begge udgaver er bygget op på samme måde. Og efter en meget sporadisk gennemgang af førsteudgaven fremstår det ikke tydeligt, om der er ændret i konklusioner og sammenfatninger - og i givet fald hvordan.

Det er bogens intention at foretage en analyse af udviklingen baseret på empiri og en teoretisk ramme. Bogen bærer ikke præg af en stringent analyse af den nævnte empiri. Derimod bærer bogen præg af, at den redegør for relevant og kendt teori samt inddrager forskellige bekendtgørelser og ministerielle rapporter, hvor de passer ind og kan eksemplificere teoretiske pointer. Det betyder, at de fire kapitler, hvor de fire overordnede samfundsmæssige udviklingstendenser gennemgås, og konsekvenserne for uddannelse præsenteres, mere fremstår som udsagn end som konklusioner på en analyse.

Det sammenfattende kapitel rummer ikke en tydelig og omfattende sammen- fatning af de gennemgåede konsekvenser for uddannelsesområdet af de fire samfundsmæssige ændringer. Så der er ikke en klar sammenhæng mellem sammenfatningen og de fire redegørende og diskuterende kapitler. Det kunne ellers have været spændende og lærerigt at få en samlet præsentation og diskussion af alle de identificerede konsekvenser af samfundsændringerne.

Rent analytisk lover bogen mere, end den holder, fordi koblingen mellem teori, empiri og konklusioner er uklar. Bogen indeholder en informativ teoretisk redegørelse for fire alment accepterede udviklingstendenser i samfundet: 1) Globalisering, 2) Overgangen til videnssamfundet, 3) Konkurrencestaten og 4) Sen-moderniteten, samt deres mere eller mindre velargumenterede sammenhæng med uddannelsesområdet. Bogen er således mere beskrivende end egentligt analyserende. Bogen kommer ikke helt i mål med at give et teoretiskanalytisk bud på sammenhængen mellem ændringer inden for den danske uddannelsesverden og den samfundsmæssige og kulturelle udvikling.

Bogens titel er som nævnt Uddannelse under naturlig forandring, og indledningskapitlet lægger op til, at den naturlige forandring i høj grad er drevet af den generelle samfundsudvikling inden for økonomi og politik. Bogen har også det teoretiske udgangspunkt, at udviklingsprocesserne er strukturationsprocesser, hvor vi som aktører kan påvirke processerne. Det er også det spor, der tages op på bogens sidste side. Dette spor er imidlertid mere eller mindre koldt i de mellemliggende kapitler.

Bogen er let tilgængelig og præsentere forskellige sociologiske teorier og kan derfor være velegnet som introduktion til en diskussion af, hvordan den generelle samfundsudvikling hænger sammen med udviklingen på uddannelsesområdet. 